\title{
Half a century of research on cattle foot and claw diseases: a scientometric analysis
}

\section{Meio século de pesquisas em doenças podais bovinas: uma análise cienciométrica}

\author{
Danilo Conrado Silva ${ }^{1 *}$; Paulo José Bastos Queiroz ${ }^{2}$; Pedro Augusto Cordeiro \\ Borges $^{3}$; Ana Carolina Barros da Rosa Pedroso ${ }^{4}$; Emmanuel Arnhold ${ }^{5}$; Alex Silva \\ da $\mathrm{Cruz}^{6}$; Aparecido Divino da $\mathrm{Cruz}^{6}$; Luiz Antônio Franco da Silva ${ }^{1}$
}

\author{
Highlights: \\ We analyzed 642 documents, most of them published in the Journal of Dairy Science. \\ Digital dermatitis is the most cattle foot and claw disease studied worldwide. \\ Laminitis-related diseases are studied more than infectious diseases. \\ In the 80's the way of studying cattle foot and claw diseases was modified. \\ This is the first scientometric study on cattle foot and claw diseases.
}

\begin{abstract}
The objective of this study was to quantitatively evaluate scientific publications on cattle foot and claw diseases using the Scopus database. A combination of keywords "hoof disease AND bovine OR cattle OR cow" was used. Publications were classified according to the type, language, subject area, source title, author, affiliation, and country/territory. The documents were grouped later into thematic topics. The diseases evaluated in each study were quantified separately and in related groups, and distributed by decades. The frequencies of the thematic topics and diseases were compared by the chi-square test for adherence. In total, 642 publications were analyzed (595 articles, 46 reviews, and 1 note). Most of these papers were written in English (518). The main subject areas were Veterinary; Agricultural and Biological Sciences; and Biochemistry, Genetics, and Molecular Biology. Journal of Dairy Science was the journal that published most articles in the area, with the best citations (SCImago Journal Rank $=1.21$ ). The authors with the highest number of publications were Johann Kofler with 19, and David Nixon Logue and Jan Keith Shearer with 18 documents each. By affiliation, the institution with the highest number of publications was the Swedish University of Agricultural Sciences. By country or territory, the United States of America (22\%), the United Kingdom (17\%), Germany (11\%), and Canada $(10 \%)$ together accounted for $60 \%$ of the publications. The classification of the documents into thematic topics resulted in four groups: Specific hoof diseases (70\%), General hoof diseases (14\%), Lameness $(11 \%)$, and Healthy hoof characterization (5\%). Eighteen foot and claw diseases have been studied,
\end{abstract}

\footnotetext{
1 Profs. Drs., Programa de Pós-Graduação em Ciência Animal, Universidade Federal de Goiás, UFG, Goiânia, GO, Brasil. E-mail: dnl.conrado@gmail.com; prof_ufg.dmv@hotmail.com

2 Prof. Dr., Curso de Medicina Veterinária, Instituto Federal do Norte de Minas Gerais, IFNMG, Salinas, MG, Brasil. E-mail: paulojose.vet@hotmail.com

3 Prof. M.e, Núcleo de Medicina Veterinária, Instituto Federal Goiano, IF Goiano, Urutaí, GO, Brasil. E-mail: pedro.borges@, ifgoiano.edu.br

4 Prof ${ }^{a}$ M.e, Programa de Pós-Graduação em Ciência Animal, UFG, Goiânia, GO, Brasil. E-mail: anacarolinapedroso@ymail.com

5 Prof. Dr., Programa de Pós-Graduação em Zootecnia, UFG, Goiânia, GO, Brasil. E-mail: emmanuelarnhold@yahoo.com.br

6 Profs. Drs., Programa de Pós-Graduação Mestrado em Genética, Pontifícia Universidade Católica de Goiás, PUC, Goiás, GO, Brasil.E-mail: a.silva.cruz@hotmail.com; acruz@pucgoias.edu.br

* Author for correspondence
} 
with the following being the most frequent: digital dermatitis (17\%), sole ulcer (15\%), and white line disease (11\%). When grouped, laminitis-related diseases represented $48 \%$ and infectious diseases represented $38 \%$ of the studies. Overall, just over half a century of research on cattle foot and claw diseases, bovine digital dermatitis is the most studied disease. Grouping related disorders revealed that laminitis-related diseases are being studied more than infectious diseases since the 1980s, from when studies on individual foot diseases in cattle increased to the detriment of studies that aimed to evaluate them as a unique problem. Our study, the first scientometric analysis in the subject area, compiles valuable information that can help researchers to develop future projects.

Key words: Bovine. Digital dermatitis. Hoof disorder. Laminitis. Sole ulcer.

\section{Resumo}

O objetivo deste estudo foi avaliar quantitativamente as publicações científicas acerca das doenças podais bovinas na base de dados SCOPUS. Foi utilizada a combinação das palavras-chave "hoof disease AND bovine OR cattle OR cow". As publicações foram classificadas de acordo com o tipo, idioma, área temática, periódico científico, autoria, filiação, e país/território. Os documentos foram agrupados em tópicos temáticos a posteriori. As doenças estudadas em cada paper foram quantificadas isoladamente e em grupos relacionados, e distribuídas por décadas. As frequências foram comparadas por teste quiquadrado para aderência. 642 publicações foram analisadas (595 artigos, 92.6\%; 46 revisões, 7.2\%; e uma nota, $0.2 \%$ ). A maioria dos documentos foi escrita em Inglês (518/81\%). As principais áreas temáticas foram: Veterinária (394); Ciências Agrárias e Biológicas (257); e Bioquímica, Genética e Biologia Molecular (131). O Journal of Dairy Science é o periódico que mais publicou artigos na área (123) e também possui as melhores citações $(\mathrm{SJR}=1.21)$. Os autores com maior número de publicações foram Johann Kofler, com 19 documentos, e David Nixon Logue e Jan Keith Shearer, com 18 documentos cada. Segundo a filiação dos documentos, a instituição com o maior número de publicações foi a Universidade Sueca de Ciências Agrárias. Por país ou território, Estados Unidos da América (22\%), Reino Unido (17\%), Alemanha (11\%) e Canadá (10\%) representaram juntos $60 \%$ das publicações. A classificação dos documentos por tópicos temáticos resultou em quatro tópicos: doenças podais específicas $(70 \%)$, doenças podais gerais (14\%), claudicação (11\%) e caracterização do casco saudável (5\%). Dezoito doenças podais foram estudadas, sendo as mais frequentes: dermatite digital (17\%), úlcera de sola (15\%) e doença da linha branca (11\%). Quando agrupadas, as doenças relacionadas à laminite representaram $48 \%$ e as doenças infecciosas $38 \%$ das doenças estudadas. Pode-se concluir que em pouco mais de meio século de pesquisas sobre doenças podais bovinas, a dermatite digital bovina é a doença mais estudada. Agrupando-se desordens relacionadas, as doenças relacionadas à laminite são mais estudadas do que as doenças infecciosas desde a década de 1980, a partir de quando as doenças podais em bovinos passaram a ser mais estudadas individualmente em detrimento aos estudos que objetivavam estudá-las como uma problemática única. Esta foi a primeira análise cienciométrica aplicada às publicações científicas acerca das doenças podais bovinas, compilando informação valiosa para auxiliar pesquisadores no desenvolvimento de projetos futuros.

Palavras-chave: Bovinos. Dermatite digital. Doenças podais. Laminite. Úlcera de sola.

\section{Introduction}

Foot and claw diseases in cattle, besides causing pain and lameness, interfere with the welfare of animals, presenting great clinical variation and resulting in poor animal performance and substantial economic losses to the farms. These negative effects are mainly attributable to increased premature death, increased mortality, decreased milk production, reduced food intake, decreased fertility, increased incidence of related diseases, and increased cost of treatments, as well as weight loss. Therefore, the foot and claw diseases constitute one of the major productive and economic obstacles to global cattle breeding (Dolecheck \& Bewley, 2018). Liang, Arnold, Stowe, Harmon \& Bewley (2017) estimated that the average cost per case of 
cattle lameness is between $\$ 185$ and $\$ 333$, based on expenditures and losses.

The first scientific studies on this subject were published during the first few decades of the $20^{\text {th }}$ century, and were mainly carried out in Germany (Greenough, 2007). In Scopus scientific database, the oldest documents pertaining to this subject date back to the early 1960s (Bömer, 1964; Batista, Shome, \& Lima, 1963; Steiner, 1963). With more than half a century of accessible research on the subject and thousands of published scientific papers, important advances have been made in elucidating clinical presentations, etiopathogenesis, epidemiology, and risk factors associated with foot and claw diseases in cattle. However, to the best of our knowledge, scientometric aspects of science and scientific production of these diseases have not been evaluated, hindering the analysis of studies in the subject area as a whole.

A scientometric study involves the quantitative evaluation of scientific and technological activities via the analysis of publications. Thus, scientometry can be defined as the science of science (Zavaraqi \& Fadaie, 2012). The scientometric methods and tools can be used to study scientific communities and evaluate their research trends. This can help researchers in a given area to build consensus and make decisions in a wide range of situations (Correia, Paredes, \& Fonseca, 2018), including development of future research projects in a subject area. Therefore, the aim of scientometric studies is to identify the highest possible number of publications in a given area.

In this milieu, since 2004, the Scopus database has become a good alternative for scientific research. As on 2014, this database, maintained by the Elsevier Company, has been internationally recognized for containing information from approximately 14,000 journals and 167 million scientific publications on various topics. These figures indicate that Scopus might contain approximately $20 \%$ more content than that of other databases (Nascimento \& Rodrigues, 2015). The aim of this study was to quantitatively evaluate scientific publications on cattle foot and claw diseases using the Scopus database.

\section{Materials and Methods}

After testing the best combination of keywords for a search to obtain the highest possible number of documents in the Scopus database, the combination "hoof disease AND bovine OR cattle OR cow" was selected. The combination of terms "bovine", "cattle", and "cow" helped retrieve a high number of documents when compared with that retrieved using each of these terms separately. The terms "hoof disorders", "podal disorders", "podal disease", "claw disorders", and "claw disease" were also tested, but they all resulted in a fewer number of documents than "hoof disease". The search with the selected keywords was limited to the article title, abstract, and keywords of the target documents. The selected date range was "All years" to "Present"; that is, we did not limit our search to a specific date of publication for documents (we included every year). Only articles, reviews, and notes were searched, with no limits for the type of access. It is important to make it clear that our study was conducted on a sampling of Scopus documents. Even with the use of keywords in order to obtain the greatest possible amount of documentation on cattle foot and claw diseases, only a fraction can be found.

The documents retrieved were read, and those that did not fit the theme foot and claw diseases in cattle were discarded. The articles that fit the proposed theme were classified according to the type (article, review, or note), language, subject area, source title, affiliation, and country/territory. In order to know the researchers who published the most in cattle foot and claw diseases, authors and co-authors were counted. Regarding the content, the documents were grouped later into thematic topics. The diseases evaluated in each study were quantified in isolation and in related groups. These quantifications were made per year, and are presented in decades, with the 2010 decade considered until July 2018. 
To compare the frequencies obtained by grouping the thematic topics and diseases over the decades and within the same decade, the chi-square test $\left(\chi^{2}\right)$ for adherence was used, considering a 5\% significance level. The software R (R Core Team, 2018) was used for the chi-square analysis and frequency calculations.

\section{Results and Discussion}

Using the combination of keywords "hoof disease AND bovine OR cattle OR cow" in the Scopus database, we obtained 868 publications. After analyzing these publications, 226 (26\%) publications were discarded; the remaining 642 (74\%) documents were related to the searched topic. The reasons for discarding the retrieved articles were as follows: studies on (1) podal diseases in other species, such as horses, pigs and small ruminants and (2) the involvement of locomotor system due to diseases that are not primary of the hooves, mainly foot-and-mouth disease. Of the 642 publications analyzed, we obtained 595 articles (92.6\%), 46 reviews $(7.2 \%)$, and 1 note $(0.2 \%)$, which highlighted the originality of research on the topic. The open access documents accounted only $2.5 \%(16 / 642)$. In a recent scientometric analysis on human Chagas cardiomyopathy (GonzálezAlcaide, Salinas, \& Ramos, 2018), only 79.6\% of all publications were journal articles, which were comparatively less than those obtained in the present study. These $79.6 \%$ of articles was followed by $11.2 \%$ of reviews.

Most of the documents were written in English $(\mathrm{n}=518,81 \%)$, followed by German $(\mathrm{n}=80$, $12 \%)$, Dutch $(\mathrm{n}=15,2 \%)$, Bulgarian $(\mathrm{n}=10$; $2 \%)$, Portuguese $(n=7 ; 1 \%)$, Russian $(n=6 ; 1 \%)$, and others $(\mathrm{n}=6 ; 1 \%)$. The trend of scientific publications in English is a reality in all areas of knowledge, as English is considered an international language (Sab, Dharani, \& Biradar, 2016). Although publications in German are not common in other areas (Friedmacher, Pakarinen, \& Rintala, 2018;
Sab et al., 2016), there is a significant number of literature published in this language in the area of cattle foot and claw diseases during the last 50 years. This reflects the importance of German speaking researchers and early works published in German at the beginning of the $20^{\text {th }}$ century (Greenough, 2007).

The classification of documents into one or more subject areas revealed the following to be the major subject areas: Veterinary (394); Agricultural and Biological Sciences (257); Biochemistry, Genetics, and Molecular Biology (131); Medicine (123); and Others (20). Together, the subject areas Veterinary, and Agricultural and Biological Sciences represent $70 \%$ of the publications by subject area. However, we should also emphasize the 131 papers classified as Biochemistry, Genetics, and Molecular Biology, of which five were published during the first half of 2018 viz., (Dolecheck, Dwyer, Overton, \& Bewley, 2018; Heringstad et al., 2018; Jacobs, Orsel, Mason, \& Barkema, 2018; Weigele, Gygax, Steiner, Wechsler, \& Burla, 2018; Wilson-Welder, Nally, Alt, Humphrey, \& Olsen, 2018). It demonstrates that studies on foot and claw diseases have been aimed at clarifying the fundamental biological mechanisms underlying these complex diseases in cattle.

By source title, the journal with the highest number of publications pertaining to foot and claw diseases in cattle is Journal of Dairy Science, with 123 papers. This was followed by Veterinary Record (61), Veterinary Journal (49), Preventive Veterinary Medicine (34), Veterinary Clinics of North America Food Animal Practice (23), Journal of the American Veterinary Medical Association (20), Deutsche Tierärztliche Wochenschrift (19), Tijdschrift Voor Diergeneeskunde (15), Acta Veterinaria Scandinavica (14), and Berliner und Münchener Tierärztliche Wochenschrift (14). The number of manuscripts published by the top five sources is presented by the year of publication in Figure 1. Superiority in terms of number of publications in Journal of Dairy Science from 2009 is apparent. 


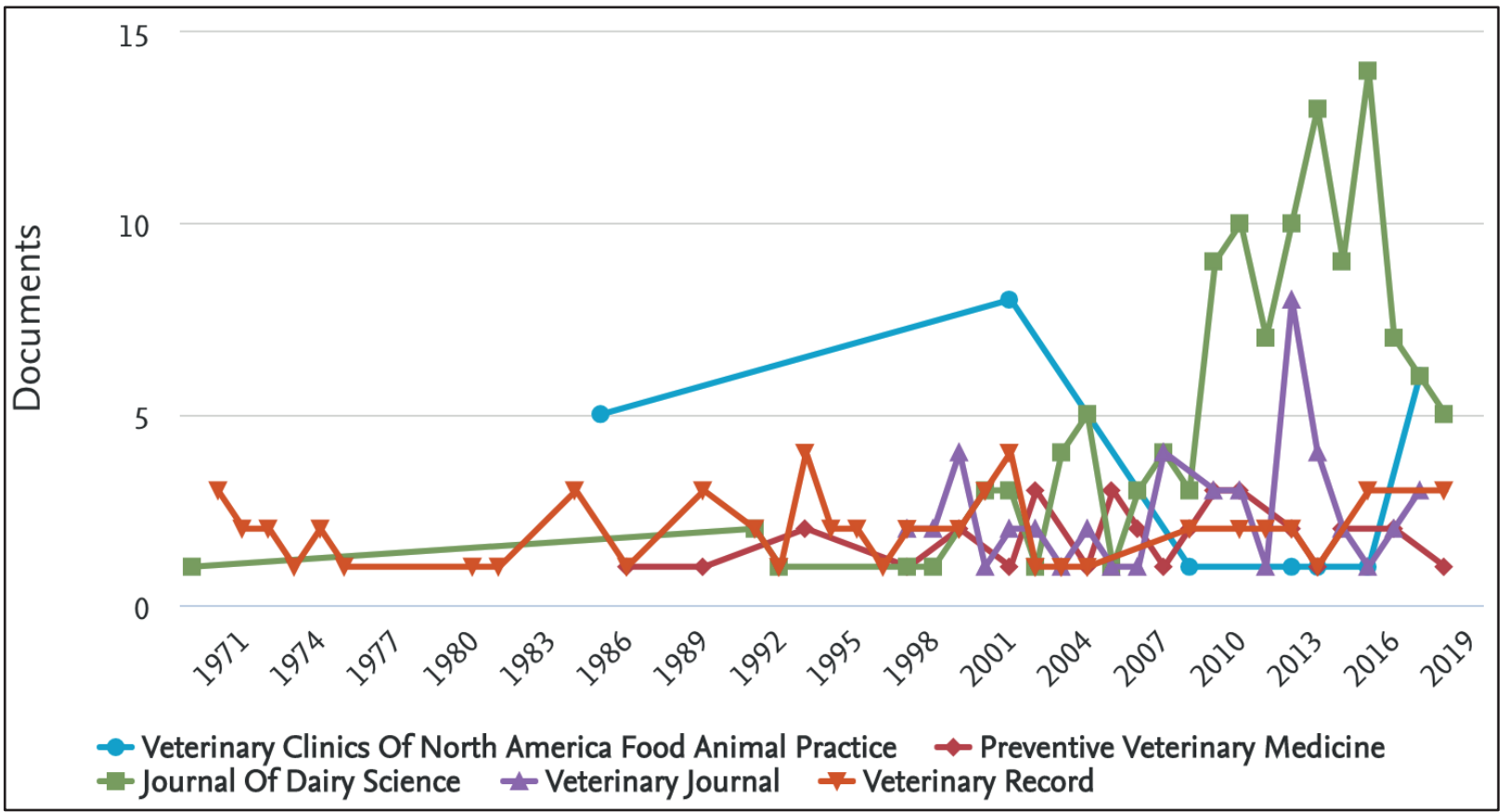

Figure 1. Manuscripts published by the top five sources by year of publication in a scientometric analysis using the keywords "hoof disease and bovine or cattle or cow" in the Scopus database.

The average SCImago Journal Rank (SJR) of 10 journals with the highest number of publications was 0.63 . Journal of Dairy Science has the highest $\mathrm{SJR}$, which is 1.21 . The SJR index, proposed by the SCImago Research Laboratory in Spain in 2007, is calculated based on the Scopus citation databases. To calculate the SJR index, a mathematical model similar to that of GooglePageRank is used, attributing different weights to the citations, according to the source that quoted the document (Jamali, Salehi-Marzijarani, \& Ayatolahi, 2014). Thus, not necessarily the most cited journal will be better ranked, as the index prioritizes the weight to the detriment of quantity of citation sources. Therefore, among the scientific journals that publish most papers on the subject of foot and claw diseases in cattle, Journal of Dairy Science publishes most studies, and it has the best citation in the area. The following is a list of journals with SJR index in descending order: Preventive Veterinary Medicine (1.04), Veterinary Journal (0.82), Journal of The American Veterinary Medical Association (0.79), Veterinary Clinics of North America Food Animal
Practice (0.64), Veterinary Record (0.56), Acta Veterinaria Scandinavica (0.46), Berliner Und Munchener Tierarztliche Wochenschrift (0.36), Deutsche Tierarztliche Wochenschrift (0.25), and Tijdschrift Voor Diergeneeskunde (0.14).

Twelve authors with 10 or more publications of the 642 documents analyzed are shown in Figure 2. Johann Kofler with 19 documents, and David Nixon Logue and Jan Keith Shearer with 18 documents each stand out. By affiliation, the 10 most prominent institutions with a high number of publications on the subject of foot and claw diseases in cattle are presented in Figure 3. The information of authors and institutions with a high number of publications in this subject can help young researchers of the area searching for bibliographic material or help establish scientific partnerships. By country or territory, $187(29 \%)$ documents were of indefinite origin, and therefore, we classified only 455 documents, which are as follows: United States (22\%), United Kingdom (17\%), Germany (11\%), and Canada (10\%) together represented $60 \%$ of the publications (Figure 4). 


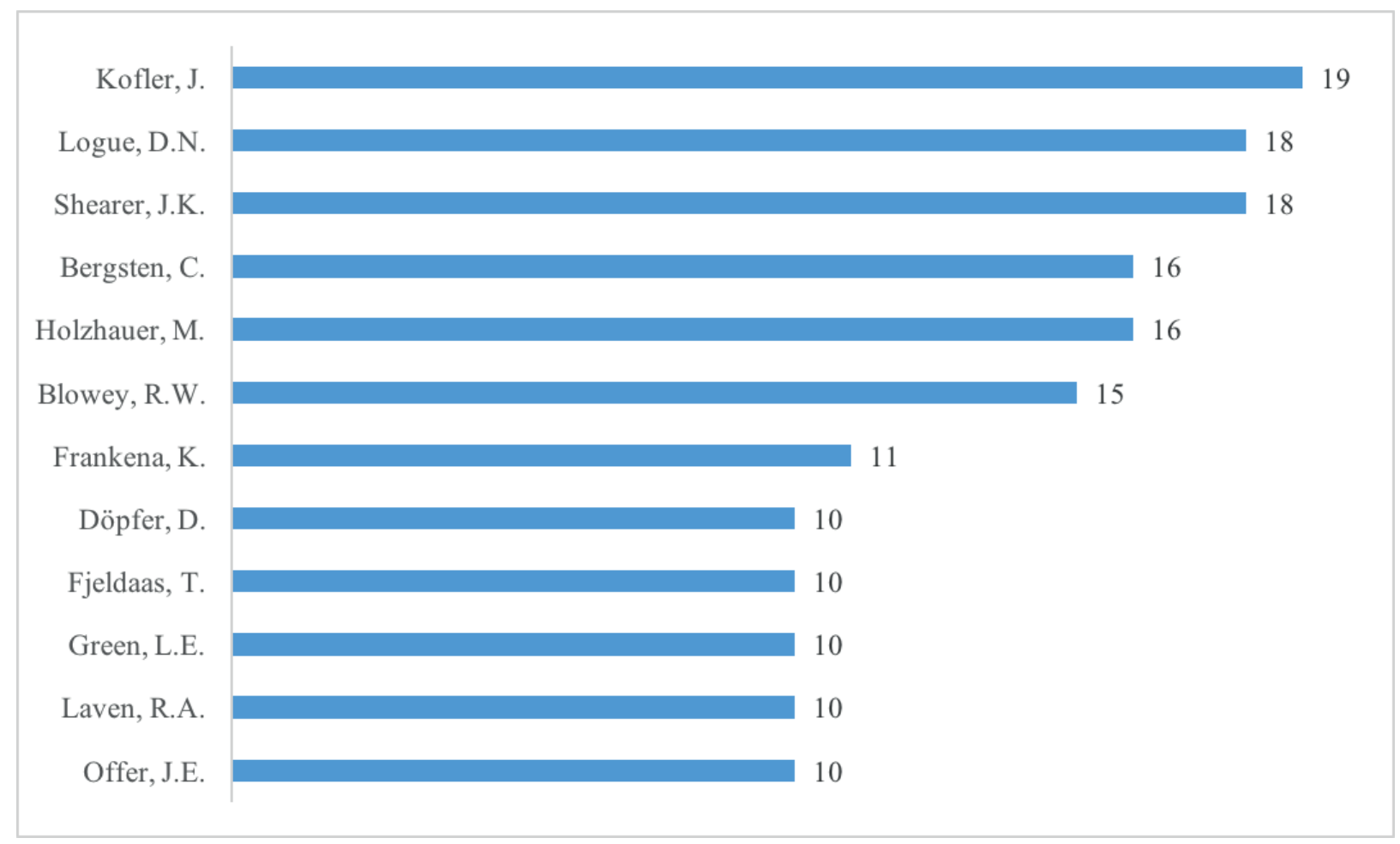

Figure 2. Twelve authors with 10 or more publications of the 642 documents analyzed in the scientometric study using the keywords "hoof disease and bovine or cattle or cow" in the Scopus database.

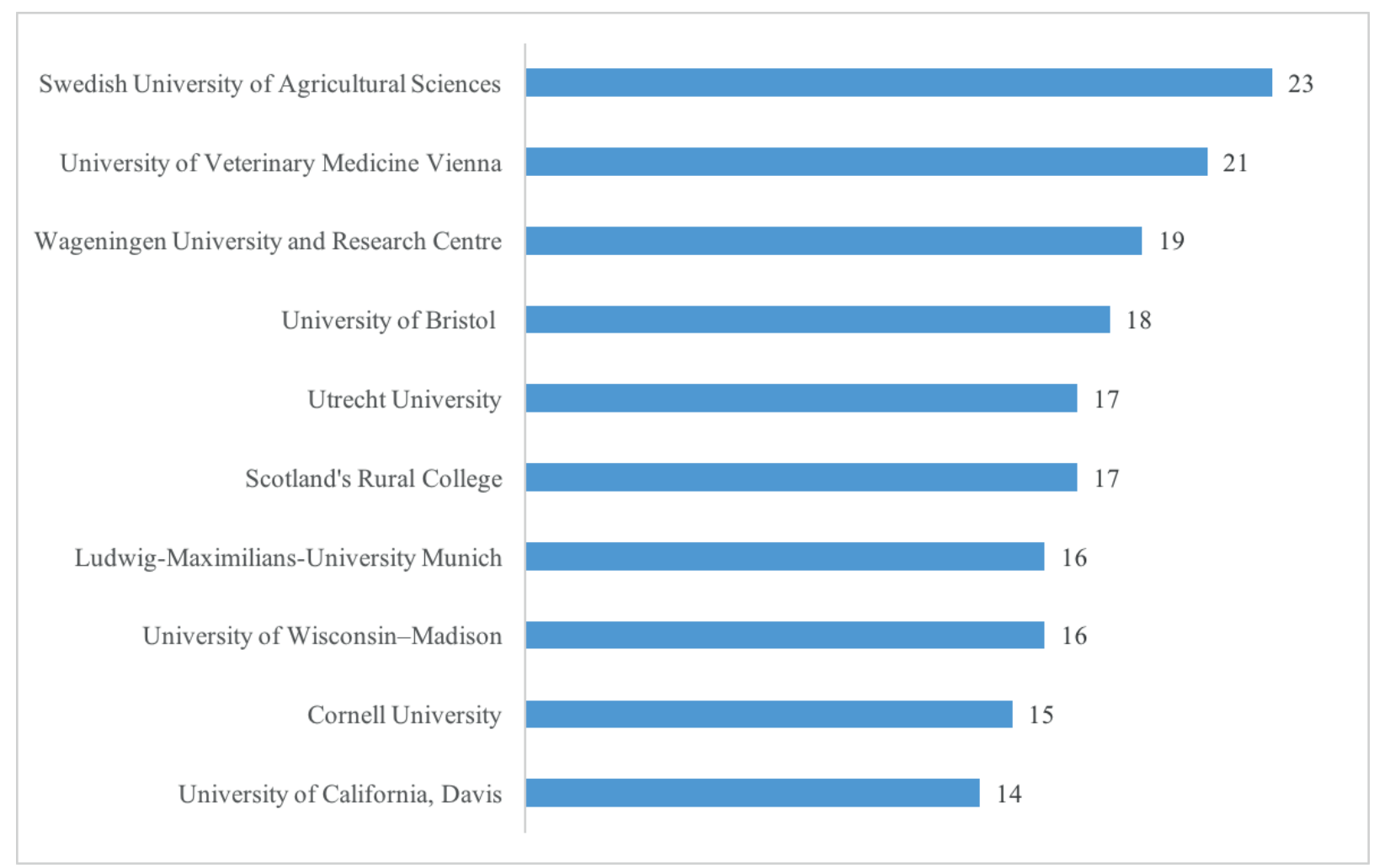

Figure 3. Number of documents by affiliation of the top 10 institutions with the highest number of studies on the subject of foot and claw diseases in cattle in the Scopus database. 


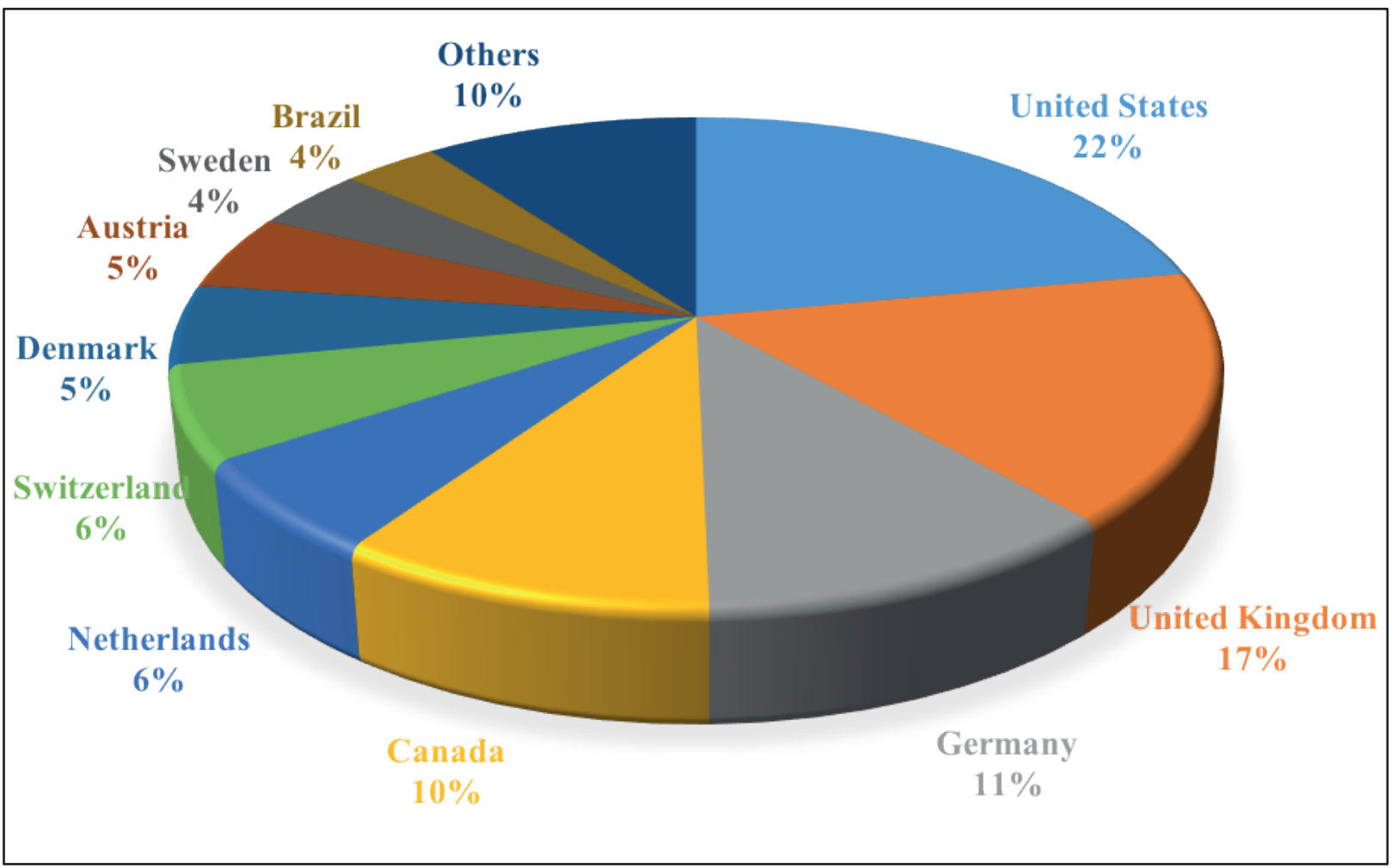

Figure 4. Percent of documents by country or territory out of 455 documents analyzed in scientometric analysis using the keywords "hoof disease and bovine or cattle or cow" in the Scopus database.

Classification of the 642 selected studies in thematic topics resulted in the following four groups (Table 1). (1) Specific hoof diseases (SHD) included publications on one or more specific hoof diseases. (2) General hoof diseases (GHD) included publications that are not specific to one or more hoof diseases, as they addressed general issues about these diseases such as risk factors, diagnostic methods, treatment, prophylaxis, epidemiology, and economic aspects. (3) Lameness (LAM) included publications pertaining to lameness in cattle and not the hoof diseases that caused it lameness was a disease focus rather than a clinical sign. (4) Healthy hoof characterization (HHC) included publications pertaining to characterization of the hoof of healthy cattle using varied techniques, and these studies form an important base for the characterization of the hoof of sick cattle.

The analysis of each thematic topic by rows in Table 1 revealed that, with the exception of GHD, in all other topics the number of publications is increasing with the decade, following the trend of total published documents $(* P<0.05)$. A comparison of the percent of publications between the topics in each column revealed that until the 1970s, the number of publications on GHD and SHD was equivalent. Since the 1980s, the number of studies on SHD has increased substantially, indicating a trend that studies on GHD have not increased after 1970s.

The trend of stagnation of GHD publications in comparison with the increase in SHD publication can be partially explained by the scientific description of diseases from the 70's, such as digital dermatitis (DD) (Watts et al., 2018), which reflected in the increased number of publications only from the later decades. In addition, technological and scientific developments created conditions for studies using more detailed diagnostic methods at the end of the 1970s and during the early 1980s (Gogoi, Nigam, 
\& Singh, 1982; Nigam \& Singh, 1980; Bodurov, Binev, \& Goranov, 1979; Yates, Rothfus, Garner, \& Cornell, 1979). In this regard, Weaver et al. (1981) reviewed the disorders of digits in ruminants with a proposal for anatomical and pathological terminology and a register for diseases. Thus, in the 1980 s, the tendency to investigate each bovine foot disease separately was intensified rather than studies that focused all diseases as a single problem.

\section{Table 1}

Frequencies of 642 studies, published from 1963 to 2018, analyzed by the decade of publication and classified into four thematic groups, in a scientometric analysis about the foot and claw diseases in cattle. The data are presented as absolute frequency and, between parentheses, as relative frequency $(\%)$

\begin{tabular}{|c|c|c|c|c|c|c|c|c|}
\hline \multirow{2}{*}{ Topic } & \multicolumn{6}{|c|}{ Decade } & \multirow{2}{*}{ Total } & \multirow{2}{*}{$* P$} \\
\hline & $1960 \mathrm{~s}$ & $1970 \mathrm{~s}$ & $1980 \mathrm{~s}$ & $1990 \mathrm{~s}$ & $2000 \mathrm{~s}$ & $2010 \mathrm{~s}$ & & \\
\hline SHD & $11(2)$ & $22(5)$ & $47(10)$ & $79(18)$ & $129(29)$ & $161(36)$ & $449(100)$ & $<0.001$ \\
\hline GHD & $10(11)$ & $22(25)$ & $19(22)$ & $9(10)$ & $15(17)$ & $13(15)$ & 88 (100) & 0.12 \\
\hline LAM & $1(1)$ & $3(4)$ & $4(6)$ & $2(3)$ & $22(31)$ & $38(54)$ & $70(100)$ & $<0.001$ \\
\hline $\mathrm{HHC}$ & $2(6)$ & $4(11)$ & $2(6)$ & $8(23)$ & $12(34)$ & $7(20)$ & $35(100)$ & 0.02 \\
\hline Total & $24(4)$ & $51(8)$ & $72(11)$ & $98(15)$ & $178(28)$ & $219(34)$ & $642(100)$ & $<0.001$ \\
\hline \multirow{2}{*}{ Topic } & \multicolumn{6}{|c|}{ Decade } & \multirow{2}{*}{ Total } & \multirow[b]{2}{*}{ - } \\
\hline & $1960 \mathrm{~s}$ & $1970 \mathrm{~s}$ & $1980 \mathrm{~s}$ & $1990 \mathrm{~s}$ & $2000 \mathrm{~s}$ & $2010 \mathrm{~s}$ & & \\
\hline SHD & $11(46)$ & $22(43)$ & $47(65)$ & $79(81)$ & $129(73)$ & $161(74)$ & $449(70)$ & - \\
\hline GHD & $10(42)$ & $22(43)$ & $19(26)$ & $9(9)$ & $15(8)$ & $13(6)$ & $88(14)$ & - \\
\hline LAM & $1(4)$ & $3(6)$ & $4(6)$ & $2(2)$ & $22(12)$ & $38(17)$ & $70(11)$ & - \\
\hline $\mathrm{HHC}$ & $2(8)$ & $4(8)$ & $2(3)$ & $8(8)$ & $12(7)$ & $7(3)$ & $35(5)$ & - \\
\hline Total & $24(100)$ & $51(100)$ & $72(100)$ & $98(100)$ & $178(100)$ & $219(100)$ & $642(100)$ & - \\
\hline${ }^{\#} P$ & 0.003 & $<0.001$ & $<0.001$ & $<0.001$ & $<0.001$ & $<0.001$ & $<0.001$ & \\
\hline
\end{tabular}

$* P=P$ value of the $\chi^{2}$ distribution in line analysis; ${ }^{*} P=P$ value of the $\chi^{2}$ distribution in column analysis.

$\mathrm{SHD}=$ Specific hoof diseases; GHD = General hoof diseases; LAM = Lameness; HHC = Healthy hoof characterization.

The number of studies that aimed to evaluate lameness as a disease rather than as a clinical sign increased from the 2000s. Weigele et al. (2018) reported that lameness is one of the most prevalent diseases affecting the well-being of cow in modern dairy production. On the contrary, lameness in dairy cattle is a result of many diseases, and a systematic approach is necessary to identify important risk factors and diagnose the predominant causes, especially if the prevalence of lameness in the herd exceeds 15\% (Nordlund, Cook, \& Oetzel, 2004).

The analysis of 449 publications that included one or more SHD revealed 18 diseases studied in
1193 cases, and some of them included cattle foot or claw diseases; they are presented in Table 2 distributed according to the decade of publication.

Digital dermatitis stood out as the disease with the highest number of publications. This disease was described in Italy during 1974, appearing as the main cause of lameness in cattle herds globally and generating considerable costs associated with its treatment and management. The pain and lameness caused by DD are among the major concerns associated with the welfare of cattle (Watts et al., 2018). Digital dermatitis lesions are observed in $70 \%-95 \%$ of dairy herds in the USA and Denmark, 
with prevalence of $20 \%-30 \%$ within herds in Europe and the USA. The high prevalence of DD results in high treatment costs, although the cost per case is generally lower than that for sole ulcer and white line disease (Nielsen, Thomsen, Green, \& Kaler, 2012). As DD was discovered in the 1970s, the first studies on DD included in the sample of this study date back to the 1980s. From the 2000s, DD became the most studied bovine foot or claw disease, accounting for $20 \%$ of the total of diseases during the decade of 2010.

Table 2

Frequencies of cattle foot and claw diseases studied between 1963 and 2018, analyzed by the decade of publication, in a scientometric analysis using the Scopus database. The data are presented as absolute frequency and, between parentheses, as relative frequency $(\%)$

\begin{tabular}{|c|c|c|c|c|c|c|c|}
\hline \multirow{2}{*}{ Disease } & \multicolumn{6}{|c|}{ Decade } & \multirow{2}{*}{ Total } \\
\hline & $1960 \mathrm{~s}$ & $1970 \mathrm{~s}$ & $1980 \mathrm{~s}$ & $1990 \mathrm{~s}$ & $2000 \mathrm{~s}$ & $2010 \mathrm{~s}$ & \\
\hline Digital dermatitis & - & - & $3(4)$ & $20(13)$ & $66(18)$ & $116(20)$ & $205(17)$ \\
\hline Sole ulcer & $1(17)$ & $3(20)$ & $15(19)$ & $21(14)$ & $56(15)$ & $85(15)$ & $181(15)$ \\
\hline White line disease & - & - & $3(4)$ & $14(10)$ & $45(12)$ & $70(12)$ & $132(11)$ \\
\hline Sole hemorrhage & - & - & $3(4)$ & $18(12)$ & $41(11)$ & $50(9)$ & $112(9)$ \\
\hline Heel horn erosion & - & - & $7(9)$ & $16(11)$ & $39(10)$ & $44(8)$ & $106(9)$ \\
\hline Laminitis & $1(17)$ & $5(33)$ & $24(30)$ & $24(16)$ & $22(6)$ & $18(3)$ & $94(8)$ \\
\hline ID & - & - & $8(10)$ & $9(6)$ & $23(6)$ & $36(6)$ & $76(6)$ \\
\hline $\mathrm{IH}$ & $3(50)$ & $2(13)$ & $3(4)$ & $3(2)$ & $16(4)$ & $31(6)$ & $58(5)$ \\
\hline IP & $1(17)$ & $1(7)$ & $5(6)$ & $2(1)$ & $16(4)$ & $30(5)$ & $55(5)$ \\
\hline Horn fissures & - & $1(7)$ & $1(1)$ & $4(3)$ & $19(5)$ & $14(2)$ & $39(3)$ \\
\hline Double sole & - & - & - & $4(3)$ & $9(2)$ & $18(3)$ & $31(3)$ \\
\hline Toe ulcer & - & - & - & $2(1)$ & $3(1)$ & $22(4)$ & $27(2)$ \\
\hline Corkscrew claws & - & - & $2(2)$ & $1(1)$ & $5(1)$ & $13(2)$ & $21(2)$ \\
\hline Abscess & - & - & $2(2)$ & $2(1)$ & $5(1)$ & $8(1)$ & $17(1)$ \\
\hline Overgrowth & - & $1(7)$ & $3(4)$ & $4(3)$ & $4(1)$ & $2(1)$ & $14(1)$ \\
\hline Thin sole & - & - & - & - & $2(1)$ & $8(1)$ & $10(1)$ \\
\hline SP & - & $2(13)$ & $1(1)$ & $1(1)$ & $3(1)$ & $2(1)$ & $9(1)$ \\
\hline $\mathrm{YD}$ & - & - & - & $3(2)$ & $2(1)$ & $1(1)$ & $6(1)$ \\
\hline Total & $6(100)$ & $15(100)$ & $80(100)$ & $148(100)$ & $376(100)$ & $568(100)$ & $1193(100)$ \\
\hline
\end{tabular}

ID - Interdigital dermatitis; IH - Interdigital hyperplasia; IP - Interdigital phlegmon; SP - Septic pododermatitis; YD - Yellow discoloration.

Between the 1970s and 1990s, laminitis was the most studied disease among the documents included in the present study. From 2000, the number of studies that contained the term 'laminitis' as the object of study declined, demonstrating a trend of disuse of the term. In 2010 , only $3 \%$ of the diseases studied in our sample group were still identified as laminitis. Greenough (2007) has described that, in the middle of that decade, scientists demonstrated that the word 'laminitis' was an inappropriate descriptor for the disorder. This assertion was based on the argument that laminae are not always the only and not necessarily the first structures in the claws that are affected, and inflammation is not invariably 
found during the early stages of the disorder. Now, researchers agree that the term 'coriosis' better describes the condition as an inflammatory insult affecting the coronary, laminar, perioplic, and solar regions of the corium (Shearer \& Van Amstel, 2017).

During the same period in which the term laminitis fell into disuse, the use of terms associated with laminitis-related disorders such as sole ulcer, white line disease, sole hemorrhage, double sole, and toe ulcer presented an absolute increase in several studies, although the relative frequency did not increase due to the substantial increase in DD. Therefore, another possible approach to analyze the occurrence of cattle foot and claw diseases is by grouping related diseases. This type of analysis has been used mainly to study infectious diseases and laminitis-related disorders (Silva et al., 2018; Ødegård, Svendsen, \& Heringstad, 2015; Van der Spek, Van Arendonk, \& Bovenhuis, 2015). Therefore, we grouped infectious diseases consisting of (inter-)DD, heel horn erosion, interdigital phlegmon, and septic pododermatitis; and laminitisrelated disorders consisting of laminitis, sole ulcer, white line disease, sole hemorrhage, double sole, and toe ulcer. The other diseases were grouped under Others (Table 3).

Table 3

Occurrence of related cattle foot and claw diseases, studied between 1963 and 2018, analyzed by the decade of publication, in a scientometric analysis using the Scopus database. The data are presented as absolute frequency and, between parentheses, as relative frequency $(\%)$

\begin{tabular}{|c|c|c|c|c|c|c|c|c|}
\hline \multirow{2}{*}{ Related diseases } & \multicolumn{6}{|c|}{ Decade } & \multirow{2}{*}{ Total } & \multirow{2}{*}{$P^{*}$} \\
\hline & $1960 \mathrm{~s}$ & $1970 \mathrm{~s}$ & $1980 \mathrm{~s}$ & $1990 \mathrm{~s}$ & $2000 \mathrm{~s}$ & $2010 \mathrm{~s}$ & & \\
\hline LRD & $2(1)$ & $8(1)$ & $45(8)$ & $83(14)$ & $176(30)$ & $263(46)$ & $577(100)$ & $<0.001$ \\
\hline Infectious & $1(1)$ & $3(1)$ & $24(5)$ & $48(11)$ & $147(32)$ & $228(50)$ & $451(100)$ & $<0.001$ \\
\hline Others & $3(2)$ & $4(2)$ & $11(7)$ & $17(10)$ & $53(32)$ & $77(47)$ & $165(100)$ & $<0.001$ \\
\hline Total & $6(1)$ & $15(1)$ & $80(7)$ & $148(12)$ & $376(31)$ & $568(48)$ & $1193(100)$ & $<0.001$ \\
\hline \multirow{2}{*}{ Related diseases } & \multicolumn{6}{|c|}{ Decade } & \multirow{2}{*}{ Total } & \\
\hline & $1960 \mathrm{~s}$ & $1970 \mathrm{~s}$ & $1980 \mathrm{~s}$ & $1990 \mathrm{~s}$ & $2000 \mathrm{~s}$ & $2010 \mathrm{~s}$ & & \\
\hline LRD & $2(33)$ & $8(53)$ & $45(56)$ & $83(56)$ & $176(47)$ & $263(46)$ & $577(48)$ & - \\
\hline Infectious & $1(17)$ & $3(20)$ & $24(30)$ & $48(32)$ & $147(39)$ & $228(40)$ & $451(38)$ & - \\
\hline Others & $3(50)$ & $4(27)$ & $11(14)$ & $17(12)$ & $53(14)$ & $77(14)$ & $165(14)$ & - \\
\hline Total & $6(100)$ & $15(100)$ & $80(100)$ & $148(100)$ & $376(100)$ & $568(100)$ & $1193(100)$ & - \\
\hline${ }^{\#} P$ & 0.6065 & 0.2466 & $<0.001$ & $<0.001$ & $<0.001$ & $<0.001$ & $<0.001$ & - \\
\hline
\end{tabular}

${ }^{*} P=\mathrm{p}$ value of the $\chi^{2}$ distribution in line analysis; ${ }^{\#} P=\mathrm{p}$ value of the $\chi^{2}$ distribution in column analysis.

LRD - Laminitis-related diseases.

Analysis of related diseases (Table 3) revealed that the groups Laminitis-related, Infectious, and Others followed a pattern of increase in the number of publications throughout all the decades, as well as the total number of publications. Furthermore, the group Laminitis-related diseases had the highest number of publications. A comparison of publication trends along columns in Tables 2 and 3 showed that DD is the most studied disease. Furthermore, grouping revealed that laminitisrelated disorders are studied more than infectious diseases. Statistically, it is apparent that this started to occur since the $1980 \mathrm{~s}$, from when the ${ }^{\#} P$ value was $<0.001$. 
According to Shearer and Van Amstel (2017), with a few exceptions, sole ulcers and white line disease are the most common claw disorders in confined dairy cattle. These disorders along with the traumatic lesions of the sole are the most common causes of lameness that affect the digit or the hoof. Traumatic lesions of the sole include thin sole toe ulcers predisposed by weakening of the sole due to excessive wear rates or over-trimming. To a large extent, these conditions are predisposed by metabolic disorders, including ruminal acidosis and laminitis, along with other physiological changes that occur during the transitional period. The mechanical stresses to which these animals are subjected on hard floors contribute to lameness (Shearer \& Van Amstel, 2017).

Based on observed publication trends, we believe that studies on DD and laminitis-related disorders will continue to be the most published by the end of this decade and probably in the next decade. In the present study, 15 documents published in 2018 were included. Of these, DD was evaluated in 13 studies ( $87 \%$ ), and 5 of them (33\%) evaluated only the disease. These data show a current trend in DD research in studies on cattle foot and claw diseases worldwide. The scientometric studies are scarce in veterinary medicine (Ueda, Karling, Takemoto, \& Pavanelli, 2013; Gupta, Ahmed, Gupta, \& Tiwari, 2015), and the absence of this type of study on cattle foot and claw diseases has made it difficult to compare the data of a study with those of other studies.

Scientometric study is an important step for the detection and description of subject areas in scientific development. From the knowledge generated by the scientometric studies, mainly on what is being researched and the influence of this production in science, decisions can be made in scientific and technological policies (Macias-Chapula, 1998). Future studies should quantitatively assess cattle foot and claw diseases and their publication trends in different databases to build a consensus on the scientific trends of this subject area.

\section{Conclusions}

Based on documents retrieved from the Scopus database, we found that in just over half a century of research on cattle foot and claw diseases, bovine digital dermatitis is the most studied disease worldwide. Grouping related disorders revealed that laminitis-related diseases are studied more than infectious diseases since the 1980s, from when studies on individual foot and claw diseases in cattle increased to the detriment of studies that aimed to study them as a unique problem. Our study compiles valuable information that can help researchers to build consensus and make decisions in a wide range of situations, including development of future research projects in the subject area. To the best of our knowledge, the present study is the first scientometric study on cattle foot and claw diseases.

\section{Acknowledgements}

The authors acknowledge the financial support of National Council for Scientific and Technological Development (CNPq).

\section{References}

Batista, A. C., Shome, S. K., \& de Lima, J. A. (1963). Streptosporangium bovinum sp. Nov. from cattle hoofs. International Journal of Dermatology, 2(1), 49-54. doi: 10.1111/ijd.1963.2.1.49

Bodurov, N., Binev, K., \& Goranov. Z. (1979). $\mathrm{X}$-ray picture of diseases of the osteoarticular and ligamentous apparatus of the digits in large ruminants. Veterinarno Medicinski Nauki, 16(7), 1218. Recuperado de https://www.ncbi.nlm.nih.gov/ pubmed/543090

Bömer, H. (1964). Contribution to the etiology of the "specific-traumatic claw ulcer". Deutsche Tierärztliche Wochenschrift, 71(10), 275-277. Recuperado de https://www.ncbi.nlm.nih.gov/ pubmed $/ 5896715$

Correia, A., Paredes, H., \& Fonseca, B. (2018). Scientometric analysis of scientific publications in CSCW. Scientometrics, 114(1), 31-89. doi: 10.1007/ s11192-017-2562-0 
Dolecheck, K. A., Dwyer, R. M., Overton, M. W., \& Bewley, J. M. (2018). A survey of United States dairy hoof care professionals on costs associated with treatment of foot disorders. Journal of Dairy Science, 101(9), 8313-8326. doi: 10.3168/jds.201814718

Dolecheck, K., \& Bewley, J. (2018). Animal board invited review: dairy cow lameness expenditures, losses and total cost. Animal, 12(7), 1462-1474. doi: $10.1017 / \mathrm{S} 1751731118000575$

Friedmacher, F., Pakarinen, M. P., \& Rintala, R. J. (2018). Congenital diaphragmatic hernia: a scientometric analysis of the global research activity and collaborative networks. Pediatric Surgery International, 34(9), 907-917. doi: 10.1007/s00383018-4304-7

Gogoi, S. N., Nigam, J. M., \& Singh, A. P. (1982). Angiographic evaluation of bovine foot abnormalities. Veterinary Radiology and Ultrasound, 23(4), 171174. doi: 10.1111/j.1740-8261.1982.tb01101.x

González-Alcaide, G., Salinas, A., \& Ramos, J. M. (2018). Scientometrics analysis of research activity and collaboration patterns in Chagas cardiomyopathy. PLOS Neglected Tropical Diseases, 12(6), 1-21. doi: 10.1371/journal.pntd.0006602

Greenough, P. R. (2007). The laminitis syndrome. In P. R. Greenough (Ed.). Bovine laminitis and lameness: a hands-on approach (Chap. 4, pp. 36-54). Philadelphia: Saunders Elsevier.

Gupta, B. M., Ahmed, K. K. M., Gupta, R., \& Tiwari, R. (2015). World camel research: a scientometric assessment, 2003-2012. Scientometrics, 102(1), 957-975. doi: 10.1007/s11192-014-1405-5

Heringstad, B., Egger-danner, C., Charfeddine, N., Pryce, J. E., Stock, K. F.; Kofler, J. F., . . . Cole, J. B. (2018). Invited review: Genetics and claw health: Opportunities to enhance claw health by genetic selection. Journal of Dairy Science, 101(6), 48014821. doi: $10.3168 /$ jds.2017-13531

Jacobs, C., Orsel, K., Mason, S., \& Barkema, H. W. (2018). Comparison of effects of routine topical treatments in the milking parlor on digital dermatitis lesions. Journal of Dairy Science, 101(6), 52555266. doi: 10.3168/jds.2017-13984

Jamali, J., Salehi-Marzijarani, M., \& Ayatollahi, S. M. T. (2014). Factors affecting journal quality indicator in Scopus (SCImago Journal Rank) in obstetrics and gynecology journals: A longitudinal study (19992013). Acta Informatica Medica, 22(6), 385-388. doi: 10.5455/aim.2014.22.385-388
Liang, D., Arnold, L. M., Stowe, C. J., Harmon, R. J., \& Bewley, J. M. (2017). Estimating US dairy clinical disease costs with a stochastic simulation model. Journal of Dairy Science, 100(2), 1472-1486. doi: 10.3168/jds.2016-11565

Macias-Chapula, C. A. (1998). O papel da informetria e da cienciometria e sua perspectiva nacional e internacional. Ciência da Informação, 27(2), 134140. doi: 10.1590/S0100-19651998000200005

Nascimento, F. A., \& Rodrigues, F. M. (2015). Growth trend of scientific literature on genetic improvement through the database Scopus. Scientometrics, 105(2), 805-816. doi: 10.1007/s11192-015-1733-0

Nielsen, B. H., Thomsen, P., Green, L. E., \& Kaler, J. A study of the dynamics of digital dermatitis in 742 lactating dairy cows. (2012). Preventive Veterinary Medicine, 104(1-2), 44-52. 10.1016/j. prevetmed.2011.10.002

Nigam, J. M., \& Singh, A. P. (1980). Radiography of bovine foot disorders. Modern Veterinary Practice. 61(7), 621-624. Recuperado de https://www.ncbi. nlm.nih.gov/pubmed/7432345

Nordlund, K. V., Cook, N. B., \& Oetzel, G. R. (2004). Investigation strategies for laminitis problem herds. Journal of Dairy Science, 87, 27-35. doi: 10.3168/ jds.S0022-0302(04)70058-2

Ødegård, C., Svendsen, M., \& Heringstad, B. (2015). Foot and leg conformation traits have a small effect on genomic predictions of claw disorders in Norwegian red cows. Journal of Dairy Science. 98(6), 4139-4147. doi: 10.3168/jds.2014-9186

R Core Team. (2018). $R$ : a language and environment for statistical computing. Vienna: R Foundation for Statistical Computing. Retrieved from https:// www.R-project.org/.

Sab, M., Dharani, K. P., \& Biradar, B. S. (2016). Scientometric study of the research performance on fishery: The Indian perspective. Journal of Advances in Library and Information Science, 5(2), 337-341. doi: 10.13140/RG.2.2.35766.70723

Shearer, J. K., \& Van Amstel, S. R. (2017). Pathogenesis and treatment of sole ulcers and white line disease. Veterinary Clinics of North America: Food and Animal Practice, 33(2), 283-300. doi: 10.1016/j. cvfa.2017.03.001

Silva, D. C., Queiroz, P. J. B., Caetano, D. M. S., Assis, B. M., Rabelo, R. E., \& Silva, L. A. F. (2018). Association between bovine digital dermatitis and annual periods of lower pluviometric precipitation in Central Brazil. Tropical Animal Health and 
Production, 50(7), 1631-1636. doi: 10.1007/s11250018-1605-8

Steiner, H. (1963). Contribution to conservative treatment of ulcerations of the sole matrix in claws of cattle. Deutsche Tierarztliche Wochenschrift, 70(7), 185187. Recuperado de https://www.researchgate.net/ publication/17288961

Ueda, B. H., Karling, L. C., Takemoto, R. M., \& Pavanelli, G. C. (2013). Parasitas de peixes de cultivo e de interesse comercial do Brasil: estudo cienciométrico. Pesquisa Veterinária Brasileira, 33(7), 851-854. doi: 10.1590/S0100-736X2013000700004

Van der Spek, D., Van Arendonk, J. A., \& Bovenhuis, H. (2015). Genome-wide association study for claw disorders and trimming status in dairy cattle. Journal of Dairy Science, 98(2), 1286-1295. doi: 10.3168/ jds.2014-8302

Watts, K. M., Fodor, C., Beninger, C., Lahiri, P., Arrazuria, R., Buck, J. de, . . Cobo, E. R. (2018). A differential innate immune response in active and chronic stages of bovine infectious digital dermatitis. Frontiers in Microbiology, 9, 1-16. doi: 10.3389/ fmicb.2018.01586
Weaver, A. D., Andersson, L., Banting, A. de L., Demerzis, P. N., Knezevic, P. F., Peterse, D. J., \& Sankovic, F. (1981). Review of disorders of the ruminant digit with proposals for anatomical and pathological terminology and recording. Veterinary Record, 108(6), 117-120. doi: 10.1136/vr.108.6.117

Weigele, H. C., Gygax, L., Steiner, A., Wechsler, B., \& Burla, J. B. (2018). Moderate lameness leads to marked behavioral changes in dairy cows. Journal of Dairy Science, 101(3), 2370-2382. doi: 10.3168/ jds.2017-13120

Wilson-Welder, J. H., Nally, J. E., Alt, D. P., Humphrey, S. B., \& Olsen, S. C. (2018). Lymphocyte proliferative responses in cattle naturally infected with digital dermatitis consist of CD8+ and $\gamma \delta$-T cells but lack CD4+ T cells. Journal of Dairy Science, 101(9), 8301-8307. doi: 10.3168/jds.2017-13913

Yates, S. G., Rothfus, J. A., Garner, G. B., \& Cornell, C. N. (1979). Videothermometry for assay of fescue foot in cattle. American Journal of Veterinary Research, 40(8), 1192-1196. Recuperado de https://www.ncbi. nlm.nih.gov/pubmed/525923

Zavaraqi, R., \& Fadaie, G. R. (2012). Scientometrics or science of science: Quantitative, qualitative or mixed one. Collnet Journal of Scientometrics and Information Management, 6(2), 273-278. doi: 10.1080/09737766.2012.10700939 
